\title{
Editors' Introduction Volume 2, Issue 1
}

\author{
Joseph F. Donnermeyer \\ Professor Emeritus/Academy Professor \\ School of Environment and Natural Resources \\ The Ohio State University \\ donnermeyer.1@gmail.com
}

\author{
Steven M. Nolt \\ Professor of History and Anabaptist Studies \\ Young Center for Anabaptist and Pietist Studies \\ Elizabethtown College \\ nolts@etown.edu
}

Published October 8, 2021

https://doi.org/10.18061/jpac.v2i1.8524

$\mathrm{T}$

his is only the third issue of the Journal of Plain Anabaptist Communities, but it has already become a popular venue for Anabaptist-related scholarship. Since late September 2020, when the inaugural issue was published, through July 31, 2021, there were 7,988 views of articles on research, fieldwork and reflections, and reviews. Excluding the editors' introductions, everything published so far was viewed at least 250 times. What this means is that JPAC may be new, but its readers deserve a big thank you for taking such a strong interest in the journal. As well, we greatly appreciate the authors for their work in creating interesting things to read and to the reviewers of submitted manuscripts who helped the editors maintain a high level of scholarship and quality writing.

On the cover of Volume 2, Issue 1 is a photo showing an arrangement of the head table used by church leaders at a gathering of Old German Baptist Brethren. This issue begins with an article by Tony Walsh, Maynooth University, Ireland, analyzing the love feast tradition among the Old German Baptists. The article offers a great opportunity for readers to learn more about this Plain group that combines the twin heritages of the Anabaptist and Pietist traditions. This issue also includes two timely articles about the Amish and COVID-19. Melissa Thomas of Ohio University and her colleagues Iva Byler, Kayla Marrero, Janet Miller, and Joseph Donnermeyer examine attitudes and beliefs about COVID-19 and vaccination, based on a survey of over 250 Amish women in the Greater Holmes County community, while Joseph M. Harasta from Kutztown University looks at the early effects of the virus on Amish in Lancaster County.

Rachel Stein of West Virginia University, along with colleagues Katie Corcoran, Carina Perrone, and Jeralynn Cossman of WVU and the University of Texas at San Antonio, present detailed demographic research from their study of the relationship between reproductive history and post-reproductive mortality among Amish women, also from the Greater Holmes County 
community. External perspectives on Plain communities are at the heart of an article on public attitudes and prejudice toward the Amish by Bryan D. Byers of Ball State University in Indiana, and his colleagues William McGuigan and James E. Jones.

$J P A C$ is pleased to include the work of Benjamin Beachy, a promising young scholar, who provides a quantitative analysis of widowhood and remarriage in Amish-Mennonite and Amish communities. Finally, Volume 1, Issue 2 includes a review symposium featuring three responses, representing three different disciplinary and situational perspectives, on Karen Johnson-Weiner's book The Lives of Amish Women, and including a response from Johnson-Weiner.

The give-and-take of the review symposium along with the collaboration represented by coauthored studies and the mix of younger and more seasoned scholars in this issue all point to the vitality of the field. We anticipate that this issue of $J P A C$ will be as warmly received and read as those of the first volume!

$J P A C$ is dedicated to publishing both empirical and theoretical work related to Plain Anabaptist communities, including, among others, the Amish, conservative Mennonites, Amish-Mennonites, Apostolic Christians, Brethren, Bruderhof, and Hutterites. JPAC articles may include emerging issues associated with Plain Anabaptist communities, diverse theoretical perspectives, and methodological approaches to the study of Plain Anabaptist groups, and significant research findings about Plain Anabaptist populations.

The Journal of Plain Anabaptist Communities is a jointly sponsored journal of the Young Center for Anabaptist and Pietist Studies at Elizabethtown College in Elizabethtown, Pennsylvania, the Amish \& Mennonite Heritage Center in Berlin, Ohio, and The Ohio State University Libraries.

$J P A C$ 's predecessor at OSU was the Journal of Amish and Plain Anabaptist Studies (JAPAS). Articles from volumes 1-6 of $J A P A S$ can still be accessed, free of charge, in the Knowledge Bank of the OSU Libraries: https://kb.osu.edu/handle/1811/54888.

If you would like to discuss ideas for manuscripts for possible publication in the journal, please contact Joe Donnermeyer (donnermeyer.1@gmail.com) or Steve Nolt (nolts@etown.edu). Visit https://plainanabaptistjournal.org/about to access additional detail about $J P A C$, including author guidelines. As these guidelines state: "Submissions should be in Microsoft Word, double-spaced, with 1-inch margins, left justification only, and no headers or footers." We allow prospective authors to select from one of two styles for citations: the American Psychological Association (APA) style (7th edition) and the Chicago Manual of Style (17th edition). In this manner, we recognize the diversity of backgrounds of prospective authors, especially because standard publication formats vary among academic disciplines. 